ISSN 1392-3196 / e-ISSN 2335-8947

Zemdirbyste-Agriculture, vol. 105, No. 2 (2018), p. 141-148

DOI 10.13080/z-a.2018.105.018

\title{
The response of Medicago sativa to aluminium toxicity under laboratory and field conditions
}

\author{
Vasily BUHAIOV ${ }^{1}$, Vitaly HORENSKYY ${ }^{1}$, Aurelija LIATUKIENE ${ }^{2}$ \\ ${ }^{1}$ Institute of Feed Research and Agriculture, \\ The National Academy of Agrarian Sciences of Ukraine \\ Yunosti 16, 21100 Vinnitsa, Ukraine \\ E-mail: bugayovvd@ukr.net \\ ${ }^{2}$ Institute of Agriculture, Lithuanian Research Centre for Agriculture and Forestry \\ Instituto 1, Akademija, Kèdainiai distr., Lithuania \\ E-mail: aurelija.liatukiene@lammc.lt
}

\begin{abstract}
Aluminium ( $\mathrm{Al}$ ) toxicity is one of the factors limiting alfalfa (Medicago sativa $\mathrm{L}$.) production on acid soils. This study aimed to determine the Al tolerance of $M$. sativa in the laboratory and field conditions, and to assess and select the most promising accessions for breeding. The response of $M$. sativa accessions of different eco-geographical origin to $\mathrm{Al}$ was evaluated in Petri dishes with filter paper moistened with different aluminium chloride $\left(\mathrm{AlCl}_{3}\right)$ concentrations: 0 (control), 1.9, 3.7, 5.6, 7.5 and $16 \mathrm{mM}$. In the laboratory conditions, the Al tolerance of the accessions was evaluated both in Lithuania (59) and in Ukraine (48). The study found that the accessions of $M$. sativa significantly differed in $\mathrm{Al}$ tolerance at the juvenile growth stage. Al toxicity inhibited seed germination and hypocotyl and root growth, particularly at 7.5 and $16 \mathrm{mM} \mathrm{AlCl}_{3}$. The Al tolerance index of germination at $7.5 \mathrm{mM}$ and $16 \mathrm{mM} \mathrm{AlCl}_{3}$ was by 1.8 and 3.3 times lower, respectively, compared with the control. The tolerance index of root and hypocotyl length of the high-tolerance accessions ranged from $28.0 \%$ to $47.0 \%$ and from $45.0 \%$ to $100 \%$, respectively at $7.5 \mathrm{mM}$. The seed yield of $M$. sativa was evaluated in the field conditions in Ukraine only. The 48 accessions were sown in an acid (pH 4.9) soil in 2013 and were assessed in 2014-2016. The M. sativa accessions 'Sevani-1', 'JJ Paso', 'Selection Manfredi' and 'Mongolian colorful hybrid' exhibited high Al tolerance both in the laboratory and field conditions and produced the highest seed yield ranging from 41.2 to $47.9 \mathrm{~g} \mathrm{~m}^{2}$, which was 1.3 times higher compared with the standard 'Synucha'.
\end{abstract}

Key words: alfalfa, aluminium tolerance, soil acidity.

\section{Introduction}

Alfalfa (Medicago sativa L.) is a very important pasture crop in many countries because of its high value, biomass yield and fast growth (Ren et al., 2010). However, the growth range of $M$. sativa is limited due to its sensitivity to acidity and aluminium (Al) toxicity. $M$. sativa biomass yield and the ability to persist are compromised due to inhibited root growth in the soils with a low $\mathrm{pH}$. Soils with an acidic environment $(\mathrm{pH}<5.5)$ are common worldwide in large areas potentially suitable for agriculture. Thus, according to the literature sources, $40 \%$ of the arable land and $70 \%$ of other lands of the world are acidic (Haug, Foy, 1984; Bot et al., 2000). The area of agricultural land affected by acidification is also increasing both in Ukraine and Lithuania (Mažvila et al., 2004; Мельник, 2010; Тютюнник и др., 2011; Гололобова, 2012). In fact, acid soils represent a major barrier to agricultural production due to the direct effects that $\mathrm{pH}$ has on the root environment and plant growth (Kochian et al., 2004; Chen et al., 2009). Aluminium toxicity inhibits root growth thus reducing yields because of insufficient intake of water and mineral nutrients (Vitorello et al., 2005). Besides, toxic levels of $\mathrm{Al}$, manganese $(\mathrm{Mn})$ and deficient levels of calcium $(\mathrm{Ca})$, magnesium $(\mathrm{Mg})$ and phosphorus $(\mathrm{P})$ are frequent under those conditions (Le et al., 2008). The examination of plant growth alterations in response to a $\mathrm{pH}$ variation is important in terms of tagging a removable source of restrained crop production and prospectively identifying genetic sources of tolerance to acid soil conditions (Fageria et al., 2009).

Several methods have been developed for evaluating $\mathrm{Al}$ tolerance in plants. These methods

Please use the following format when citing the article:

Buhaiov V., Horenskyy V., Liatukienė A. 2018. The response of Medicago sativa to aluminium toxicity under laboratory and field conditions. Zemdirbyste-Agriculture, 105 (2): 141-148 DOI 10.13080/z-a.2018.105.018 
contribute to the evaluation of physiological processes underlying this trait. The genetics and physiology of $M$. sativa tolerance to $\mathrm{Al}$ as well as tolerance screening techniques have been comprehensively studied during the last decade (Sledge et al., 2002; 2005; Narasimhamoorthy et al., 2007; Pan et al., 2008; Bouton, 2012; Khu et al., 2012). Comparisons of screening techniques revealed medium to high correlations of tolerance factors among them. Hydroponics, filter paper in dishes, natural soils and chemically modified soils, root staining methods (Zhang et al., 2007; Pan et al., 2008) have been found to successfully and efficiently serve for search of tolerant populations as well as for development of more tolerant populations (Charman et al., 2008). However, the main constraint for an efficient development of populations possessing desirable tolerance level is a deficiency of agronomically advanced populations with a high tolerance level (Sledge et al., 2005).

The objective of this study was to screen accessions of alfalfa (Medicago sativa $\mathrm{L}$.) for aluminium (Al) tolerance at a juvenile stage in the laboratory conditions and to identify the highest seed yielding accessions in the field trials on an acid soil and to select the most promising accessions for further breeding.

\section{Materials and methods}

A total of alfalfa (Medicago sativa L.) 107 accessions of different eco-geographical origin were studied, of which 48 were analysed in the laboratory of the Institute of Feed Research and Agriculture of Podillya, the National Academy of Agrarian Sciences of Ukraine, and 59 accessions were analysed in the laboratory of Institute of Agriculture, Lithuanian Research Centre for Agriculture and Forestry. To estimate aluminium (Al) tolerance of $M$. sativa, the following concentrations of the working solution were used: 0 (control), 1.9, 3.7, 5.6, 7.5 and $16 \mathrm{mM} \mathrm{AlCl}_{3}$. The $\mathrm{pH}$ of the $\mathrm{Al}$ solutions was 4.5. Thirty seeds of the same size were used for the analysis at each $\mathrm{Al}$ concentration. The seeds were placed in Petri dishes on moist 2-layer filter paper and incubated at $20^{\circ} \mathrm{C}$ in the dark. Measurements of root and hypocotyl length were conducted on the $7^{\text {th }}$ day (Léon et al., 2005). Al tolerance index of germination (IG), indices of root (IRL) and hypocotyl (IHL) length were calculated according to the following formula: the IG, IRL and IHL = germination, length of root or hypocotyl at a certain concentration / germination rate, length of root or hypocotyl in the control treatment $\times 100 \%$.

The $M$. sativa accessions were divided into three groups according to Al tolerance (Pan et al., 2008). The high-tolerance accessions had the best germination at 1.9, 3.7 and $5.6 \mathrm{mM} \mathrm{AlCl}_{3}$, good or medium - at 7.5 and $16 \mathrm{mM}$. The highest root and hypocotyl length was at 1.9, 3.7 and 5.6 mM. Medium-tolerant accessions showed high stability of germination at the lowest concentration, or medium at 7.5 and $16 \mathrm{mM}$, or poor at $16 \mathrm{mM}$.

The highest hypocotyl and root length was at 1.9, 3.7 and $5.6 \mathrm{mM}$, or medium at $5.6 \mathrm{mM}$ and very poor at $16 \mathrm{mM}$ (Fig. 1). Low-tolerance accessions differed in germination stability at 7.5 and $16 \mathrm{mM}$; however, the same accessions showed poor germination at $5.6 \mathrm{mM}$. The highest root and hypocotyl length was at 1.9 and $3.7 \mathrm{mM}$, while the lowest - at 5.6, 7.5 and $16 \mathrm{mM} \mathrm{AlCl}_{3}$ (Table 1).

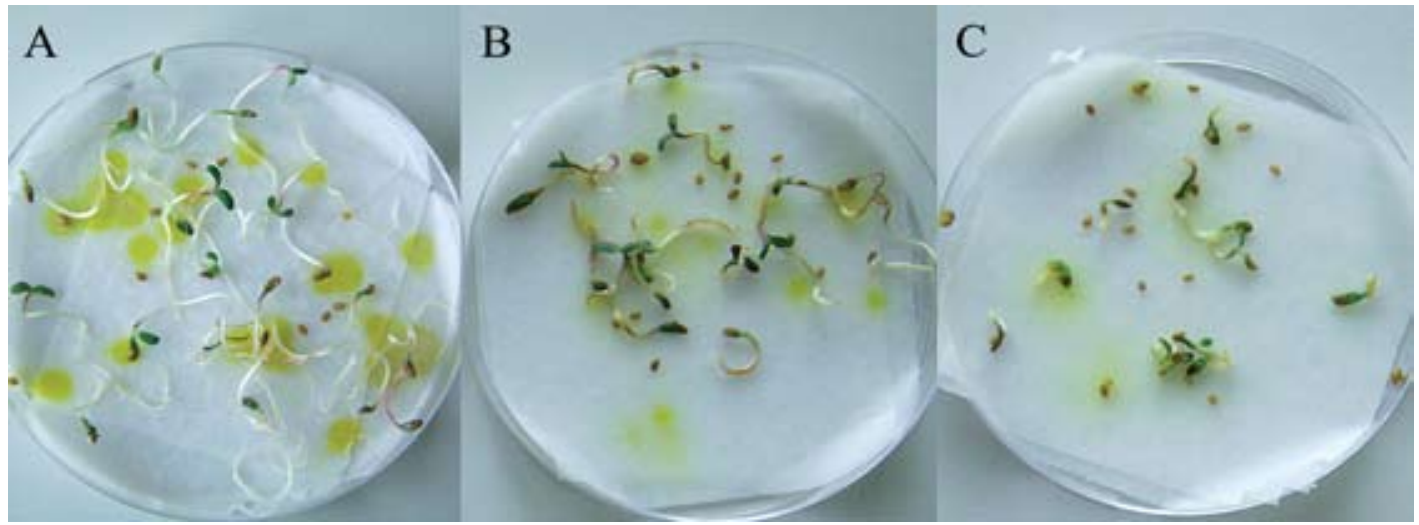

Figure 1. Deformation of Medicago sativa hypocotyls at 0 (A), 7.5 (B) and 16 (C) $\mathrm{mM}$ of aluminium chloride $\left(\mathrm{AlCl}_{3}\right)$ in the solution

Table 1. Aluminium (Al) tolerance index as influenced by the aluminium chloride $\left(\mathrm{AlCl}_{3}\right)$ concentrations in the laboratory conditions in Lithuania and Ukraine

\begin{tabular}{|c|c|c|c|c|c|}
\hline \multirow{2}{*}{ Al tolerance index } & \multicolumn{5}{|c|}{ Concentration of $\mathrm{AlCl}_{3} \mathrm{mM}$} \\
\hline & 1.9 & 3.7 & 5.6 & 7.5 & 16 \\
\hline High & $>100 \%$ & $>50 \%$ & $>40 \%$ & $>35 \%$ & $>25 \%$ \\
\hline Medium & $90-100 \%$ & $40-50 \%$ & $30-40 \%$ & $25-35 \%$ & $15-10 \%$ \\
\hline Low & $<90 \%$ & $<40 \%$ & $<30 \%$ & $<25 \%$ & $<10 \%$ \\
\hline
\end{tabular}

To check the results of laboratory evaluation of $\mathrm{Al}$ tolerance, experiments in the field conditions were conducted in 2013 at Institute of Feed Research and Agriculture of Podillya, Ukraine. The soil of the experimental site is grey podzol with a $\mathrm{pH}$ of 4.9 , available Al 2.7-2.8 $\mathrm{mg} \mathrm{kg}^{-1}$ soil and hydrolytic acidity of 2.8-3.1 mg $\mathrm{eq}^{-1} 100 \mathrm{~g}$ soil. A nursery collection of 48 accessions was sown by a wide-sowing method $(45 \mathrm{~cm})$, the plot size was 
$3 \mathrm{~m}^{2}$, and two replications were used. Cultivar 'Synucha' was used as the standard. The plants of 'Synucha' showed the best tolerance to acidity in previous studies. Field research, monitoring, recording and measurements were conducted according to instructions (Константинова и др., 1969; Жаринов, 1979).

Hydrothermal conditions during the study period were characterized by uneven distribution of rainfall

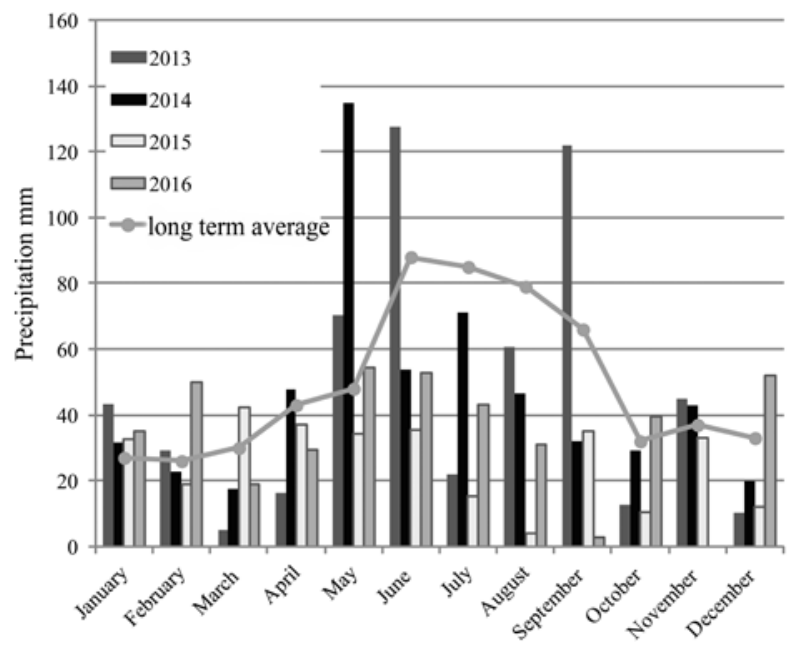

and temperature. The highest rainfall was recorded in 2013 and 2014 (563.1 and $549.7 \mathrm{~mm}$, respectively), and in 2015 and in 2016 elevated temperature and lack of moisture adversely affected the formation of pods. Hydrothermal conditions of the period 2013-2016 are shown in Figure 2.

Graphs and calculations were made using software Microsoft Excel and STATISTICA, version 10.

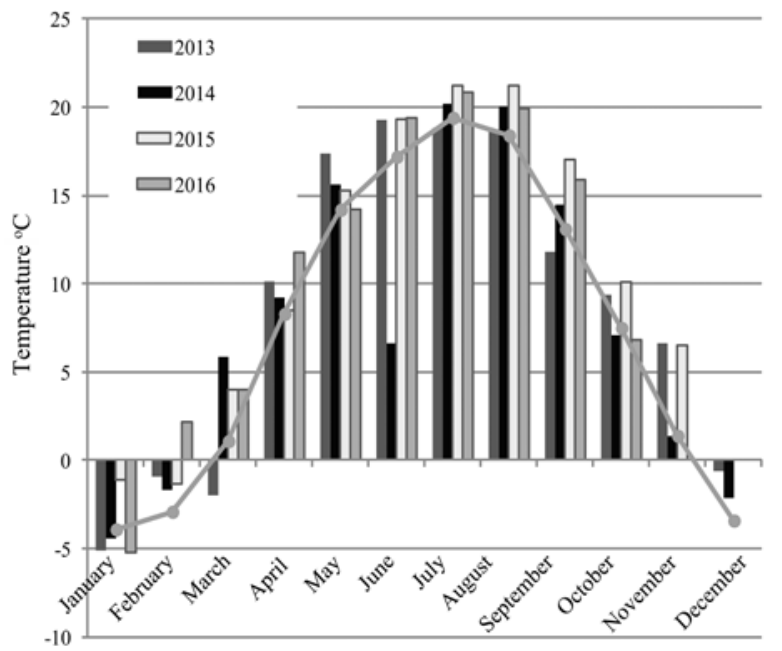

Figure 2. Precipitation and temperature regime of 2013-2016 (Podillya, Ukraine)

\section{Results and discussion}

The results of the laboratory evaluation of $\mathrm{Al}$ tolerance of $M$. sativa in Lithuania and Ukraine showed considerable differentiation of the collection accessions. Al was found to inhibit $M$. sativa seed germination, root and hypocotyl elongation (Fig. 3). These effects became much more pronounced with increased Al concentrations and differed among the $M$. sativa 107 accessions analysed. These results are consistent with literature reports (Ying et al., 2005).

At low $\mathrm{Al}$ concentrations, the differences in germination rates among the tested cultivars were small. The Al tolerance index for germination at low concentrations of 1.9 and $3.7 \mathrm{mM}$ ranged from $49.5 \%$ to $117.5 \%$ and from $42.0 \%$ to $115.7 \%$, respectively. The total

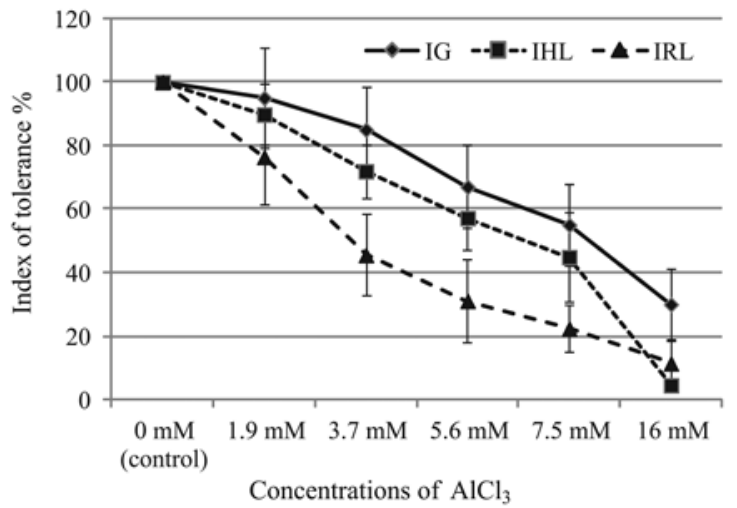

Figure 3. Aluminium $(\mathrm{Al})$ tolerance index for germination (IG), hypocotyl (IHL) and root (IRL) length at juvenile stage of Medicago sativa 107 accessions in the laboratory conditions average index for germination at low $\mathrm{Al}$ concentrations of 1.9 and $3.7 \mathrm{mM}$ was $95.0 \%$ and $85.0 \%$, respectively (Fig. 3). However, at increased Al concentrations, the tolerance index for germination decreased by 1.8 and 3.3 times at 7.5 and $16 \mathrm{mM} \mathrm{AlCl}_{3}$ compared with the control treatment. The tolerance index for germination for the accessions tested in Lithuania ranged from $0 \%$ to $77.2 \%$ at $7.5 \mathrm{mM}$ and from $0 \%$ to $65.3 \%$ at $16 \mathrm{mM}$. The tolerance index for germination for the accessions tested in Ukraine ranged from $20 \%$ to $85.0 \%$ at $7.5 \mathrm{mM}$ and from $13.0 \%$ to $78.0 \%$ at $16 \mathrm{mM}$.

At $1.9,3.7,5.6$ and $7.5 \mathrm{mM} \mathrm{AlCl}_{3}$, the $\mathrm{Al}$ tolerance index of roots was by 1.2, 1.6, 1.8 and 2.0 times lower, respectively, compared with that of hypocotyls (Fig. 3). The tolerance index of hypocotyls and roots of the tested accessions in Lithuania ranged from $0 \%$ to $58.8 \%$ and from $0 \%$ to $44.0 \%$, respectively at $7.5 \mathrm{mM}$ $\mathrm{AlCl}_{3}$. The tolerance index of hypocotyls and roots of the accessions tested in Ukraine ranged from $20 \%$ to $107 \%$ and from $13.0 \%$ to $47.0 \%$, respectively at $7.5 \mathrm{mM} \mathrm{AlCl}_{3}$. The accessions of $M$. sativa were very strongly impaired by $\mathrm{Al}$ toxicity at $16 \mathrm{mM} \mathrm{AlCl}_{3}$. Only $2.8 \%$ of the total tested accessions formed seedlings and $54.2 \%$ formed roots at $16 \mathrm{mM} \mathrm{AlCl}_{3}$. The tolerance index of hypocotyls and roots of all tested accessions was $4.5 \%$ and $11.4 \%$, respectively at $16 \mathrm{mM} \mathrm{AlCl}_{3}$ (Fig. 3).

According to the data obtained at a concentration of $1.9 \mathrm{mM} \mathrm{AlCl}_{3}, 20$ samples showed increased root growth at the early stages of growth and development, particularly high-tolerance samples (Table 2). For M. sativa accessions 'Selection Manfredi' and 'Villigar' (Argentina), 'Magalie' (France), 'Regina' (Ukraine), commercial No. 2-52-75 (UK), 'Peruvian pubescent' 
Table 2. The aluminium (Al) tolerance index (\%) of root and hypocotyl length at juvenile stage of Medicago sativa in the laboratory conditions in Ukraine

\begin{tabular}{|c|c|c|c|c|c|c|c|c|c|}
\hline \multirow{3}{*}{ Accession } & \multirow{3}{*}{ Origin } & \multicolumn{4}{|c|}{$\begin{array}{c}\text { Al tolerance index } \\
\text { of root length }\end{array}$} & \multicolumn{4}{|c|}{$\begin{array}{l}\text { Al tolerance index } \\
\text { of hypocotyl length }\end{array}$} \\
\hline & & \multicolumn{8}{|c|}{ solution $\mathrm{AlCl}_{3} \mathrm{mM}$} \\
\hline & & 1.9 & 3.7 & 5.6 & 7.5 & 1.9 & 3.7 & 5.6 & 7.5 \\
\hline \multicolumn{10}{|c|}{ High-tolerance } \\
\hline Synucha (standard) & Ukraine & $105 \pm 4$ & $60 \pm 9$ & $50 \pm 7$ & $30 \pm 10$ & $110 \pm 2$ & $89 \pm 2$ & $86 \pm 7$ & $48 \pm 2$ \\
\hline Saratov-1 & Russia & $145 \pm 10$ & $94 \pm 17$ & $68 \pm 2$ & $31 \pm 2$ & $117 \pm 3$ & $108 \pm 12$ & $95 \pm 1$ & $60 \pm 4$ \\
\hline Sevani-1 & Russia & $137 \pm 3$ & $58 \pm 7$ & $47 \pm 5$ & $31 \pm 8$ & $94 \pm 4$ & $88 \pm 1$ & $60 \pm 3$ & $45 \pm 17$ \\
\hline Oahasa & Mexico & $147 \pm 9$ & $90 \pm 6$ & $47 \pm 1$ & $42 \pm 4$ & $124 \pm 1$ & $108 \pm 6$ & $104 \pm 1$ & $92 \pm 1$ \\
\hline Vertibenda & Germany & $118 \pm 7$ & $88 \pm 3$ & $59 \pm 1$ & $35 \pm 1$ & $125 \pm 8$ & $96 \pm 10$ & $75 \pm 8$ & $68 \pm 9$ \\
\hline Mega & Sweden & $123 \pm 2$ & $65 \pm 20$ & $53 \pm 8$ & $35 \pm 10$ & $114 \pm 5$ & $89 \pm 7$ & $74 \pm 3$ & $56 \pm 5$ \\
\hline JJ Paso & Argentina & $119 \pm 4$ & $62 \pm 13$ & $43 \pm 7$ & $37 \pm 3$ & $109 \pm 1$ & $84 \pm 10$ & $69 \pm 12$ & $48 \pm 3$ \\
\hline Selection Manfredi & Argentina & $90 \pm 3$ & $71 \pm 3$ & $48 \pm 4$ & $28 \pm 2$ & $119 \pm 3$ & $111 \pm 2$ & $100 \pm 6$ & $80 \pm 10$ \\
\hline Villigar & Argentina & $100 \pm 4$ & $87 \pm 9$ & $52 \pm 13$ & $42 \pm 5$ & 100 & $94 \pm 4$ & $75 \pm 2$ & $65 \pm 5$ \\
\hline Magalie & France & $100 \pm 4$ & $66 \pm 8$ & $43 \pm 2$ & $28 \pm 2$ & $113 \pm 13$ & $117 \pm 9$ & $108 \pm 7$ & $100 \pm 23$ \\
\hline Mesopotamian & Iraq & $67 \pm 2$ & $47 \pm 2$ & $47 \pm 2$ & $40 \pm 10$ & $76 \pm 3$ & $72 \pm 6$ & $66 \pm 13$ & $52 \pm 9$ \\
\hline Mongolian colorful hybrid & Mongolia & $82 \pm 8$ & $73 \pm 2$ & $53 \pm 2$ & $47 \pm 2$ & $105 \pm 2$ & $81 \pm 1$ & $68 \pm 2$ & $53 \pm 6$ \\
\hline \multicolumn{10}{|c|}{ Medium-tolerance } \\
\hline Bilgorod-86 & Russia & $109 \pm 5$ & $72 \pm 1$ & $36 \pm 4$ & $27 \pm 9$ & $124 \pm 11$ & $108 \pm 1$ & $83 \pm 1$ & $64 \pm 2$ \\
\hline Regina & Ukraine & $94 \pm 2$ & $66 \pm 3$ & $33 \pm 3$ & $27 \pm 1$ & $130 \pm 2$ & $104 \pm 1$ & $95 \pm 1$ & $47 \pm 1$ \\
\hline Zarnytsa & Ukraine & $138 \pm 7$ & $66 \pm 1$ & $33 \pm 7$ & $33 \pm 7$ & $126 \pm 2$ & $113 \pm 3$ & $104 \pm 4$ & $78 \pm 2$ \\
\hline Commercial No. 2-52-75 & UK & $95 \pm 1$ & $57 \pm 1$ & $38 \pm 1$ & $33 \pm 2$ & $106 \pm 8$ & $82 \pm 10$ & $74 \pm 7$ & $40 \pm 8$ \\
\hline Peruvian pubescent & Peru & $100 \pm 8$ & $59 \pm 2$ & $36 \pm 2$ & $32 \pm 6$ & $122 \pm 4$ & $111 \pm 5$ & 100 & $107 \pm 9$ \\
\hline Hybrid Milfenie & France & $68 \pm 5$ & $59 \pm 9$ & $47 \pm 3$ & $29 \pm 9$ & $96 \pm 10$ & $72 \pm 2$ & $61 \pm 4$ & $44 \pm 2$ \\
\hline Washol & USA & $75 \pm 2$ & $46 \pm 7$ & $33 \pm 1$ & $17 \pm 1$ & $97 \pm 12$ & $82 \pm 3$ & $64 \pm 8$ & $48 \pm 8$ \\
\hline Local de Calchin & Argentina & $71 \pm 1$ & $47 \pm 10$ & $41 \pm 7$ & $29 \pm 4$ & $93 \pm 1$ & $82 \pm 2$ & $61 \pm 5$ & $50 \pm 7$ \\
\hline Local & Argentina & $52 \pm 8$ & $37 \pm 3$ & $32 \pm 4$ & $26 \pm 2$ & $113 \pm 6$ & $93 \pm 5$ & $70 \pm 2$ & $51 \pm 8$ \\
\hline \multicolumn{10}{|c|}{ Low-tolerance } \\
\hline Unitro & Ukraine & $112 \pm 6$ & $58 \pm 5$ & $23 \pm 2$ & $17 \pm 1$ & $99 \pm 1$ & $88 \pm 2$ & $67 \pm 3$ & $53 \pm 2$ \\
\hline Nizona & Cuba & $76 \pm 2$ & $43 \pm 3$ & $33 \pm 5$ & $23 \pm 4$ & $118 \pm 5$ & $111 \pm 5$ & $96 \pm 1$ & $85 \pm 1$ \\
\hline Liguen & Chile & 100 & $91 \pm 13$ & $43 \pm 14$ & $26 \pm 4$ & $126 \pm 1$ & $94 \pm 4$ & $81 \pm 2$ & $52 \pm 4$ \\
\hline
\end{tabular}

(Peru) and 'Liguen' (Chile) Al tolerance index of root length ranged between $90-100 \%$, while 'Local' (Argentina) showed the lowest result 52.0\% compared with other accessions (Table 2). In the laboratory conditions in Lithuania, the Lithuanian cultivars 'Antanè', 'Birutè' and 'Žydrūnè' showed the highest tolerance index for germination $98.7,99.2$ and $98.5 \%$, respectively at $1.9 \mathrm{mM} \mathrm{AlCl}_{3}$ compared with the other cultivars tested.

According to the classification, at the juvenile stage of $M$. sativa, collection accessions 'Saratov-1' and 'Sevani-1' (Russia), 'Oahasa' (Mexico), 'Vertibenda' (Germany), 'Mega' (Sweden), 'JJ Paso' and 'Villigar' (Argentina), 'Mesopotamian' (Iraq) and 'Mongolian colorful hybrid' (Mongolia) are of high-tolerance compared with the standard 'Synucha'. These accessions showed the highest $\mathrm{Al}$ tolerance index for root length, which ranged from $31.0 \%$ to $47.0 \%$ at $7.5 \mathrm{mM} \mathrm{AlCl}_{3}$. However, the tolerance index of root length of the accessions 'Selection Manfredi' (Argentina) and 'Magalie' (France) was similar to that of the standard 'Synucha' $-28 \%$ at $7.5 \mathrm{mM} \mathrm{AlCl}_{3}$ (Table 2). The highest-tolerance accessions differed in tolerance index for hypocotyl length, which ranged from $45.0 \%$ to $100 \%$ at $7.5 \mathrm{mM} \mathrm{AlCl}_{3}$. However, the accession 'Sevani-1' (Russia) was similar to the standard for hypocotyl length $45.0 \%$ (Table 2). The Lithuanian cultivars 'Antanè',
'Birutė' and 'Žydrūnè' showed a high tolerance index for hypocotyl length, 39.6, 53.3 and $48.6 \%$, respectively at $7.5 \mathrm{mM} \mathrm{AlCl}_{3}$ compared with the other cultivars tested in Lithuania.

The medium-tolerance index for $\mathrm{Al}$ was observed in 16 accessions: 'Bilgorod-86' (Russia), 'Regina' and 'Zarnytsa' (Ukraine), commercial No. 2-5275 (UK), 'Peruvian pubescent' (Peru), 'Hybrid Milfenie' (France), 'Washol' (USA), 'Local de Calchin' and 'Local' (Argentina). The tolerance index of root and hypocotyl length of these accessions ranged from $17.0 \%$ to $33.0 \%$ and from $40 \%$ to $78.0 \%$ at $7.5 \mathrm{mMAlCl}_{3}$, respectively. The accession 'Peruvian pubescent' significantly differed by the longest hypocotyls. The tolerance index of hypocotyl length of this accession was the best $107 \%$, or 2.2 times higher compared with the standard 'Synucha' (Table 2).

The germination of $M$. sativa accessions in different acid environments in the laboratory conditions showed that the accessions tested in Ukraine and Lithuania significantly differed in $\mathrm{Al}$ tolerance at 7.5 and $16 \mathrm{mM}$ $\mathrm{AlCl}_{3}$. The accessions of $M$. sativa with high and medium tolerance to $\mathrm{Al}$ showed relatively good germination, although the seedlings showed poor development at $16 \mathrm{mM} \mathrm{AlCl}_{3}$ (Fig. 1). The seedlings with high and medium $\mathrm{Al}$ tolerance at $7.5 \mathrm{mM} \mathrm{AlCl}$ can be selected as promising material for $\mathrm{Al}$ tolerance breeding (Fig. 4). 

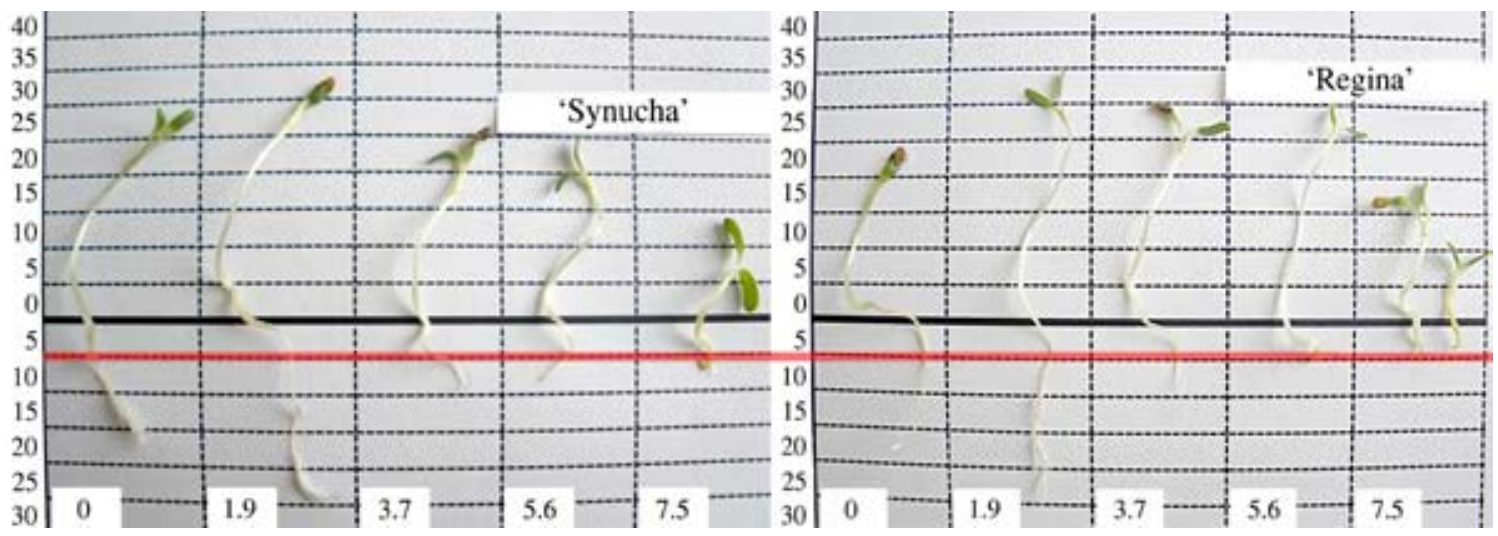

Figure 4. The response of root system and hypocotyls of the Medicago sativa high-tolerance cultivar 'Synucha' and medium-tolerance cultivar 'Regina' to 0 (control), 1.9, 3.7, 5.6 and $7.5 \mathrm{mM} \mathrm{AlCl}_{3}$

The Petri dish method showed an efficient possibility to select Al resistant seedlings using simple materials and lesser work input as compared with the other methods described in the literature (Šlepetys et al., 2007; Barone et al., 2008; Pan et al., 2008). Possibly, only hydroponic screening could be comparable by efficiency but only in the case of further growing of selected seedlings (Narasimhamoorthy et al., 2007; Scott et al., 2008).

Other methods, especially based on soil techniques, are hardly suitable for screening of thousands of seeds per accession in temperate climate. However, these methods could be successfully applied for the final screening steps when several populations have been selected after multiple cycles of recurrent selections. The recurrent selection is more effective, if new populations are formed from older cultivars, because they are more tolerant of acid soils and the new genotypes selected from these cultivars are also Al-tolerant. The study showed that the selected older cultivars of $M$. sativa are widespread due to their ability to produce high yield of biomass, but seed productivity of these cultivars is low and unstable (Бугайов и др., 2012). The M. sativa cultivars more recently introduced in the breeding program are characterised by high biomass and seed yield. However, the soil acidity negatively impacts on growth, especially at flower and seed development stages. The sensitive accessions of $M$. sativa developed very poorly and the pods fell down (Писковацкий, 2002; Бугайов и др., 2014). The development of flowers, elements of flowers, pods, also seed productivity of $M$. sativa are the main indicators of its stability in acid soils.

The current study conducted in an acid soil showed that the accessions of $M$. sativa commercial No. 2-52-75 (UK), 'Sevani-1' and 'Bilgorod-86' (Russia), 'Mega' (Sweden), 'JJ Paso', 'Selection Manfredi' and 'Local' (Argentina), 'Peruvian pubescent' (Peru), 'Magalie' (France), 'Mesopotamian' (Iraq), 'Mongolian colorful hybrid' (Mongolia) and 'Washol' (USA) were distinguished by seed yield. In this study, we determined that high-tolerance $(75 \%)$ and medium-tolerance $(25 \%)$ accessions formed $12-105 \%$ higher seed yield than the standard 'Synucha'. The seed yield of the standard amounted to $31.3 \mathrm{~g} \mathrm{~m}^{-2}$ in 2014. The same accessions of $M$. sativa showed high or medium tolerance to Al in the laboratory conditions; however, they formed significantly lower seed yield in acid soil in the first year of use (Table 3).

The findings of the current study showed that $M$. sativa accessions differed in seed productivity. Soil acidity and meteorological conditions had a marked influenced on seed yield, especially during flowering and seed development time (May-July). The seed yield was influenced by high temperatures and shortage of rainfall in 2015, average seed yield of the experiment was 46.6 $\mathrm{g} \mathrm{m}^{-2}$. The seed yield was 3.4 times lower in a rainy year of 2014 and 1.6 times lower in a normal year of 2016 compared with a dry year of 2015 . The average seed yield of the experiment was $13.6 \mathrm{~g} \mathrm{~m}^{-2}$ in 2014 and $28.2 \mathrm{~g} \mathrm{~m}^{-2}$ in 2016. The seed yield also depended on the biological characteristics of the accessions, activity of pollinators and rainfall during flowering. The seed yield of the experiment was very low in 2014-2016, due the large potential for production of biomass and large number of flowers. The situation was even more complicated due to the relatively short productive life of $M$. sativa crop stand for seed production in Ukraine. However, seed yield can be higher, when flowering period is characterized by low relative humidity and moderate to high temperatures and pod development period by moderate humidity and temperatures. These climatic conditions favour long periods for pollinator activity and later seed development (Cane, 2002). Higher temperatures and lower precipitation resulted in high seed yield in dry 2015. Also, the seed yield was affected by the low precipitation, high temperatures and biological characteristics of accessions in 2016. This was shown by the high significant positive correlation coefficient $\left(r=0.88^{*}\right)$ of seed yield between rainy 2014 and normal 2016. Also medium positive significant correlation coefficient $\left(r=0.616^{*}\right)$ of seed yield was determined between dry 2015 and normal 2016, and low positive coefficient $(r=0.422)$ of seed yield was between rainy 2014 and dry 2015.

The study of three years showed that $58.3 \%$ of high- and $37.5 \%$ of medium-tolerance accessions produced $9-43 \%$ higher seed yield than the standard 'Synucha'. Other accessions of $M$. sativa (33.0\%) were of low-tolerance to $\mathrm{Al}$ in the laboratory conditions but they produced higher seed yield in the field conditions. 
Table 3. Seed productivity of Medicago sativa accessions on acid (pH 4.9) soils in Ukraine, 2014-2016

\begin{tabular}{|c|c|c|c|c|c|c|c|c|}
\hline \multirow[b]{2}{*}{ Accession } & \multirow{2}{*}{$\begin{array}{c}\text { National } \\
\text { catalogue } \\
\text { number }\end{array}$} & \multirow[b]{2}{*}{ Origin } & \multicolumn{6}{|c|}{$\begin{array}{l}\text { Seed yield } \\
\mathrm{g} \mathrm{m}^{-2}\end{array}$} \\
\hline & & & 2014 & 2015 & 2016 & 2014-2016 & $\begin{array}{c}\text { compared to } \\
\text { standard } \\
+/-\end{array}$ & $\begin{array}{c}\text { compared to } \\
\text { standard } \\
\%\end{array}$ \\
\hline Synucha (standard) & UJ0700134 & Ukraine & 31.3 & 53 & 16 & 33.4 & - & 100 \\
\hline Saratov-1 & UJ0700186 & Russia & 19.8 & 41 & 10.9 & 23.9 & -9.5 & 72 \\
\hline Sevani-1 & UJ0700189 & Russia & 51.6 & 70.2 & 21.9 & 47.9 & 14.5 & 143 \\
\hline Oahasa & UJ0700371 & Mexico & 30.9 & 38.3 & 12.5 & 27.2 & -6.2 & 81 \\
\hline Vertibenda & UJ0700390 & Germany & 9.4 & 42.5 & 9.3 & 20.4 & -13 & 61 \\
\hline Mega & UJ0700365 & Sweden & 35.1 & 51.2 & 15.5 & 34 & 0.6 & 102 \\
\hline JJ Paso & UJ0700364 & Argentina & 60.3 & 44.5 & 18.9 & 41.2 & 7.8 & 123 \\
\hline Selection Manfredi & UJ0700336 & Argentina & 48.8 & 68.4 & 21.1 & 46.1 & 12.7 & 138 \\
\hline Villigar & UJ0700361 & Argentina & 23.3 & 49.8 & 13.2 & 28.8 & -4.6 & 86 \\
\hline Magalie & UJ0700381 & France & 38.4 & 37.1 & 13.6 & 29.7 & -3.7 & 89 \\
\hline Mesopotamian & UJ0700428 & Iraq & 38.5 & 47.6 & 15.5 & 33.9 & 0.5 & 101 \\
\hline Mongolian colorful hybrid & UJ0700188 & Mongolia & 55.6 & 48.5 & 26 & 43.4 & 10 & 130 \\
\hline Bilgorod-86 & UJ0700185 & Russia & 68.7 & 52.8 & 21.9 & 47.8 & 14.4 & 143 \\
\hline Regina & UJ0700031 & Ukraine & 17.4 & 43.4 & 11 & 23.9 & -9.5 & 72 \\
\hline Zarnytsa & UJ0700007 & Ukraine & 12.2 & 40.3 & 9.4 & 20.6 & -12.8 & 62 \\
\hline Commercial No. 2-52-75 & UJ0700195 & UK & 44.4 & 53.5 & 17.6 & 38.5 & 5.1 & 115 \\
\hline Peruvian pubescent & UJ0700414 & Peru & 37.5 & 68.2 & 19 & 41.5 & 8.1 & 124 \\
\hline Hybrid Milfenie & UJ0700346 & France & 14.2 & 62.2 & 13.7 & 30 & -3.4 & 90 \\
\hline Washol & UJ0700404 & USA & 64.2 & 28.7 & 16.7 & 36.5 & 3.1 & 109 \\
\hline Local de Calchin & UJ0700356 & Argentina & 9.7 & 46.7 & 10.2 & 22.2 & -11.2 & 66 \\
\hline Local & UJ0700338 & Argentina & 44.5 & 58 & 18.4 & 40.3 & 6.9 & 121 \\
\hline Unitro & UJ0700392 & Ukraine & 17.2 & 28.4 & 8.2 & 17.9 & -15.5 & 54 \\
\hline Nizona & UJ0700368 & Cuba & 12 & 41.3 & 9.6 & 20.9 & -12.5 & 63 \\
\hline \multirow[t]{2}{*}{ Liguen } & UJ0700429 & Chile & 7.2 & 47.2 & 9.8 & 21.4 & -12 & 64 \\
\hline & $\mathrm{LSD}_{05}$ & & 1.6 & 2.64 & 0.77 & & & \\
\hline
\end{tabular}

\section{Conclusions}

1. The laboratory and field experiment methods used to test aluminium (Al) tolerance of the alfalfa (Medicago sativa L.) accessions were effective to select high- and medium-tolerance accessions. However, the field experiment method proved to be more effective as it better differentiated the accessions according to their Al tolerance. The evaluation of $M$. sativa accessions in the field conditions on an acid $(\mathrm{pH} 4.9)$ soil evidenced that $58.3 \%$ of the accessions were of high- and $37.5 \%$ medium-tolerance, their seed yield was either comparable to that of the standard 'Synucha' or 9-43\% higher.

2. At $7.5 \mathrm{mM} \mathrm{AlCl}_{3}$, the cultivars of $M$. sativa tested in Lithuania showed 2.2 times lower tolerance index for hypocotyl length and 1.8 times lower tolerance index for root length compared with the cultivars tested in Ukraine. The Lithuanian cultivars 'Antanè', 'Birutè' and 'Žydrūne' showed the highest tolerance index for hypocotyl length at this concentration. In the laboratory study in Ukraine, there were selected 12 high-tolerance and 16 medium-tolerance accessions using a tolerance index of root and hypocotyl length at $7.5 \mathrm{mM} \mathrm{AlCl}_{3}$.

Received 24052017 Accepted 24012018

\section{References}

1. Barone P., Rosellini D., LaFayete P., Bouton J., Veronesi F., Parrott W. 2008. Bacterial citrate synthase expression and soil aluminum tolerance in transgenic alfalfa. Plant Cell Reports, 27 (5): 893-901. https://doi.org/10.1007/s00299-008-0517-x

2. Bot A. J., Nachtergaele F. O., Young A. 2000. Land resource potential and constraints at regional and country levels. World soil resources report No. 90. FAO, Rome, 114 p.

3. Bouton J. H. 2012. Breeding lucerne for persistence. Crop Pasture Science, 63 (2): 95-106. https://doi.org/10.1071/CP12009

4. Cane H. J. 2002. Pollinating bees (Hymenoptera: Apiformes) of U.S. alfalfa compared for rates of pod and seed set. Journal of Economic Entomology, 95 (1): 22-27. https://doi.org/10.1603/0022-0493-95.1.22

5. Charman N., Ballard R. A., Humphries A. W., Auricht G. C. 2008. Improving lucerne nodulation at low $\mathrm{pH}$ : contribution of rhizobial and plant genotype to the nodulation of lucerne seedlings growing in solution culture at $\mathrm{pH}$ 5. Australian Journal of Experimental Agriculture, 48 (4): 512-517. https://doi.org/10.1071/EA07138

6. Chen G., Li G. D., Conyers M. K., Cullis B. R. 2009. Long-term liming regime increases prime lamb production on acid soils. Experimental Agriculture, 45 (2): 221-234. https://doi.org/10.1017/S0014479708007497 
7. Fageria N. K., Baligar V. C., Li Y. C. 2009. Differential soil acidity tolerance of tropical legume cover crops. Communications in Soil Science and Plant Analysis, 40 (7-8): 1148-1160. https://doi.org/10.1080/00103620902754127

8. Haug A., Foy C. E. 1984. Molecular aspects of aluminium toxicity. Critical Reviews in Plant Sciences, 1 (4): 345-373. https://doi.org/10.1080/07352688409382184

9. Khu D.-M., Reyno R., Brummer E. C., Monteros M. J. 2012. Screening methods for aluminum tolerance in alfalfa. Crop Science, 52: 161-167. https://doi.org/10.2135/cropsci2011.05.0256

10. Kochian L. V., Hoekenga O. A., Piñeros M. A. 2004. How do crop plants tolerate acid soils? Mechanisms of aluminum tolerance and phosphorous efficiency. Annual Review of Plant Biology, 55: 459-493. https://doi.org/10.1146/annurev.arplant.55.031903.141655

11. Mažvila J., Adomaitis T., Eitminavičius L. 2004. Changes in the acidity of Lithuania's soils as affected on not liming. Zemdirbyste-Agriculture, 88 (4): 3-20 (in Lithuanian).

12. Le T. M. H., Collins R. N., Waite T. D. 2008. Influence of metal ions and $\mathrm{pH}$ on the hydraulic properties of potential acid sulfate soils. Journal of Hydrology, 356 (1-2): 261-270.

13. Léon V., Rabier J., Notonier R., Barhelémy R., Moreau X., Bouraïma-Madjèbi S., Viano J., Pineau R. 2005. Effects of three nickel salts on germinating seeds of Grevillea exul var. rubiginosa, an endemic serpentine Proteaceae. Annals of Botany, 95 (4): 609-618. https://doi.org/10.1093/aob/mci066

14. Narasimhamoorthy B., Blancaflor E. B., Bouton J. H., Payton M. E., Sledge M. K. 2007. A comparison of hydroponics, soil, and root staining methods for evaluation of aluminum tolerance in Medicago truncatula (barrel medic) germplasm. Crop Science, 47 (1): 321-328. https://doi.org/10.2135/cropsci2006.03.0147

15. Pan X.-B., Zhu C., Cheng C. 2008. Assessment of techniques for screening alfalfa cultivars for aluminium tolerance. Euphytica, 164 (2): 541-549. https://doi.org/10.1007/s10681-008-9751-0

16. Ren W. B., Zhang Y., Deng B., Guo H., Cheng L., Liu Y. 2010. Effect of space flight factors on alfalfa seeds. African Journal of Biotechnology, 9 (43): 7273-7279.

17. Scott B. J., Ewing M. A., Williams R., Humphries A. W., Coombes N. E. 2008. Tolerance of aluminium toxicity in annual Medicago species and lucerne. Australian Journal of Experimental Agriculture, 48 (4): 499-511. https://doi.org/10.1071/EA07137

18. Sledge M. K., Bouton J. H., Dall'Agnoll M., Parrott W. A., Kochert G. 2002. Identification and conformation of aluminum tolerance QTL in diploid Medicago sativa subs. coerulea. Crop Science, 42 (4): 1121-1128. https://doi.org/10.2135/cropsci2002.1121

19. Sledge M. K. Pechter P., Payton M. E. 2005. Aluminum tolerance in Medicago truncatula germplasm. Crop Science, 45 (5): 2001-2004. https://doi.org/10.2135/cropsci2004.0673

20. Šlepetys J., Šikšnianienè J. B., Kadžiulienè Ž., Brazaitytė A., Duchovskis P. 2007. The effect of higher temperatures, acid substrate, and cadmium and cooper on lucerne. Zemdirbyste-Agriculture, 94 (3): 47-59 (in Lithuanian).

21. Vitorello V. A., Capaldi F. R., Stefanuto V. A. 2005. Recent advances in aluminum toxicity and resistance in higher plants. Brazilian Journal of Plant Physiology, 17 (1): 129-143.

https://doi.org/10.1590/S1677-04202005000100011
22. Ying X.-F., Liu P., Xu G.-D., Lu Q.-D., Zhu S.-L. 2005. Screening of soybean genotypes with tolerance to aluminum toxicity and study of the screening indices. Chinese Journal of Oil Crop Sciences, 27 (1): 46-51

23. Zhang X., Humphries A., Auricht G. 2007. Genetic variability and inheritance of aluminium tolerance as indicated by long root regrowth in lucerne (Medicago sativa L.). Euphytica, 157 (1-2): 177-184. https://doi.org/10.1007/s10681-007-9409-3

24. Бугайов В. Д., Мамалыга В. С., Максимов А. Н. 2012. Методы эдафической селекции люцерны. Тезисы докладов III международной конференции «Идеи Н. И. Вавилова в современном мире». Санкт-Петербург, c.263-264 (in Russian).

25. Бугайов В. Д., Мамалига В. С., Горенський В. М., Максімов А. М. 2014. Оцінка та створення вихідного матеріалу для селекції люцерни в умовах підвищеної кислотності грунтів. Збірник наукових праць: Фактори експериментальної еволюції організмів. Київ, № 15 , c. $153-155$ (in Ukrainian).

26. Гололобова О. О. 2012. Екологічний стан компонентів довкілля природного заповідного фонду Харківської області. Вісник Харьковский национальный университет имени В. Н. Каразина. Екологія, 1004 (7): 91-97 (in Ukrainian).

27. Жаринов В. И. 1979. К методике оценки исходного материала при селекции люцерны на повышение семенной продуктивности. Новые методы создания и использования исходного материала для селекции растений. Київ, с. 233-242 (in Russian).

28. Константинова А. М., Вощинин, А. С. Новоселова П. А. 1969. Методика селекции многолетних трав. Москва, 108 c. (in Russian).

29. Мельник А. Ф. 2010. Закислення грунтів - проблема землеробства. Пропозиція, 9: 80-81 (in Ukrainian).

30. Писковацкий Ю. М. 2002. Селекция люцерны на устойчивость к кислым почвам. Интродукция и освоение нетрадиционных и редких с. х. растений: сборник научных работ. Ульяновск, с. 39-42 (in Russian).

31. Тютюнник С. Ю. Ребенков С. О. Бобков В. М., Долін В. В. 2011. Органічні форми знаходження алюмінію у грунтах лісових екосистем. Збірник наукових праць Інституту геохімії навколишнього середовища. Київ, 19: 130-138 (in Ukrainian). 
ISSN 1392-3196 / e-ISSN 2335-8947

Zemdirbyste-Agriculture, vol. 105, No. 2 (2018), p. 141-148

DOI 10.13080/z-a.2018.105.018

\title{
Mèlynžiedės liucernos reakcija ị aliuminio toksiškumą laboratorinėmis ir lauko sąlygomis
}

\author{
V. Buhaiov ${ }^{1}$, V. Horenskyy ${ }^{1}$, A. Liatukiené $\dot{2}^{2}$ \\ ${ }^{1}$ Ukrainos nacionalinės agrarinių mokslų akademijos Pašarų ir žemės ūkio mokslų institutas \\ ${ }^{2}$ Lietuvos agrarinių ir miškų mokslų centro Žemdirbystès institutas
}

\section{Santrauka}

Aliuminio (Al) toksiškumas yra vienas veiksnių, ribojančių liucernos produktyvumą rūgščiuose dirvožemiuose. Tyrimo tikslas - nustatyti liucernos tolerantiškumą aliuminiui laboratorinèmis ir lauko sąlygomis, pagal ši požymi įvertinti ir atrinkti perspektyvius liucernos pavyzdžius selekcijai. Skirtingos geografinès kilmès liucernos selekcinès medžiagos reakcija ị aliuminio poveikị buvo tirta Petri lèkštelių metodu, filtrinị popierių sudrèkinus skirtingos koncentracijos terpèmis: 0 (kontrolinis variantas), 1,9, 3,7, 5,6, 7,5 ir $16 \mathrm{mM}$ aliuminio chlorido $\left(\mathrm{AlCl}_{3}\right)$. Mèlynžiedès liucernos (Medicago sativa L.) selekcinès medžiagos tolerantiškumo aliuminiui tyrimas laboratorinėmis sąlygomis buvo atliktas Lietuvoje ir Ukrainoje. Lietuvoje buvo tirti 59, Ukrainoje - 48 pavyzdžiai. Liucernos sèklų derliaus tyrimai ir vertinimas lauko sąlygomis buvo atlikti tik Ukrainoje. Ukrainoje liucernos selekciné medžiaga buvo pasėta ị rūgštu ( $\mathrm{pH}$ 4,9) dirvožemị 2013 m., vertinta 20142016 m. Tyrimų metu nustatyta, kad augalų augimo juveniliniu tarpsniu liucernos selekcinè medžiaga esmingai skyrèsi tolerantiškumu aliuminiui. Aliuminio 7,5 ir $16 \mathrm{mM}$ terpių koncentracijos slopino sẻklų dygimą, daigelių ir šaknelių augimą. Sèklų dygimo tolerantiškumo indeksas esant 7,5 ir $16 \mathrm{mM} \mathrm{AlCl}_{3}$ koncentracijoms buvo mažesnis nei kontrolinio varianto atitinkamai 1,8 ir 3,3 karto. Esant 7,5 mM koncentracijai didelio atsparumo aliuminiui liucernos selekcinès medžiagos šaknelių tolerantiškumo indeksas kito nuo 28,0 iki 47,0 \%, daigelių - nuo 45,0 iki 100 \%. Iš tirtos selekcinès medžiagos išsiskyrè veislių 'Sevani-1', 'JJ Paso', 'Selection Manfredi' ir 'Mongolian colorful hybrid' liucernos, kurios pasižymėjo aukštu tolerantiškumo lygiu tiriant laboratorinėmis bei lauko sąlygomis ir subrandino didžiausią sèklų derlių. Jis kito nuo 41,2 iki 47,9 g m². Šie genotipai sẻklų derliumi standartinę veislę 'Synucha' lenkè 1,3 karto.

Reikšminiai žodžiai: dirvožemio rūgštumas, Medicago sativa, tolerantiškumas aliuminiui. 